\title{
ENCAPSULATION EFFICIENCY AND THERMAL STABILITY OF ORANGE ESSENTIAL OIL MICROENCAPSULATED BY SPRAY DRYING AND BY COACERVATION
}

PRISCILA S. MÜLLER* CAMILA A. PERUSSELLO**

\begin{abstract}
Orange essential oil was microencapsulated by spray drying using maltodextrin and modified starch as carrier agents, and by coacervation using sodium alginate. The influence of different microencapsulation methods and carriers on the microscopic and thermal characteristics of the product and on the encapsulation efficiency of the microparticles was investigated. According to a technique based on headspace extraction coupled to gas chromatography, the encapsulation efficiencies were above $99 \%$ for both methods, and the oil was composed mainly of D-limonene $(95.7 \%)$ and mircene (1.66 \%). Coacervation and spray drying produced microparticles of $908.63 \mu \mathrm{m}$ and $1.02 \mu \mathrm{m}$, respectively, which increased the thermal stability of the oil. Nonetheless, the coacervated microparticles showed higher thermal stability and boiling point than the spray-dried ones.
\end{abstract}

KEY-WORDS: COACERVATION, SPRAY DRYING, ORANGE ESSENTIAL OIL, MICROENCAPSULATION, THERMAL STABILITY.

\footnotetext{
*psm_6@hotmail.com

** camila_ea@yahoo.com.br

*** agnesps@gmail.com

**** sfzawadzki@onda.com.br
} 


\section{INTRODUCTION}

The production of orange (Citrus sinensis, L. Osbeck) and industrialization of juice are concentrated in four countries accounting for one third of the world production. Brazil has a prominent position in the production of essential oil, next to India, China and Indonesia, which are considered the four major world producers. Brazil is the third largest exporter of essential oil in the world, after only the USA and France. However, $91 \%$ of the whole production consists of essential oil of citrus, mainly oranges ( $80 \%$ ), by-products of the juice industry (BIZZO, HOVELL and REZENDE, 2009). The world market for essential oil yields profits of about US\$ 15 million/year, growing around $11 \%$ per year. The orange essential oil is obtained by cold pressing and may be used to enhance the aroma of citric juices and for flavoring products such as soft drinks, candies, ice creams, cakes and biscuits (SANTOS, SERAFINI and CASSEL, 2003). Orange oil is a complex mixture that can contain up to 300 different chemical compounds, which are divided into two fractions: non-volatile, mainly composed of carotenoids, flavonoids and coumarins, and volatile, comprising aldehydes, ketones, terpenic hydrocarbons such as limonene and myrcene, alcohols and esters. Because of its composition, the orange essential oil has low water solubility and high tendency to oxidation. The volatile fraction of citrus oils in general represents 94 to $98 \%$ of the whole oil and consists of more than 1000 compounds, manly of which are present only as traces. D-limonene is the major component of the orange peel oil, assuming concentrations of $90-96 \%$. One of the greatest technological hurdles regarding the orange essential oil is its preservation during processing and storage, since it is highly volatile and the majority of its components are sensitive to oxidation due to temperature, light and oxygen (GARGANO, COSTA and COSTA, 2008; POURASHOURI et al., 2014; RAMAKRISHNAN et al., 2014).

Among the various strategies used to extend the stability of essential oils, microencapsulation is of remarkable importance. The process comprises the encapsulation of solids or liquids into polymeric matrices such as maltodextrin, starches, alginates and others. The protection ascribed to the polymeric wall avoids undesirable chemical and sensory changes in the encapsulated material even during long storage periods. Hydrophilic microparticles increase the ingredients solubility and facilitate the product incorporation as food additives. In addition, microencapsulation reduces the material-environment reactivity, protecting them from moisture, light and heat, masks flavors and assists the dispersion of water-insoluble substances in aqueous media (COSTA et al., 2015; COUTO et al., 2012; TAN, CHAN and HENG, 2009; TEODORO et al., 2014; VELÁZQUEZ-CONTRERAS, OSORIO-REVILLA and GALLARDO-VELÁZQUEZ, 2014).

Various techniques have been employed in the production of microparticles, such as spray drying, spray cooling, coacervation, extrusion, centrifugal extrusion, coating, fluidized bed, liposomes, inclusion complexation and nanoprecipitation (BOTREL et al., 2015; CALISKAM and DIRIM, 2013.; DONG et al., 2013). The microencapsulation method must be simple, reproducible, fast, and easy to implement on an industrial scale and little dependent on the solubility characteristics of the active substance to be encapsulated and the polymer being used (ESTEVINHO et al., 2013; FERNANDES et al., 2014; MARQUES et al., 2014; MATALANIS et al., 2012).

This paper compares the microencapsulation of orange essential oil conducted by two different methods: spray drying (using maltodextrin and modified starch by octenylsuccinate as carriers) and coacervation (using sodium alginate as a carrier). The microencapsulations carried out by coacervation and by spray-drying have some advantages over other methods: the properties and quality of the product are more efficiently controlled, both methods can be applied to heatsensitive products and provide high continuous productions using simple equipment, the particles obtained are highly soluble and stable, and the techniques are efficient and require low cost. The smaller size is an advantage that the microparticles obtained by spray drying have compared to the coacervated ones. The advantages of the microparticles obtained by coacervation over the spraydried ones is that materials with uniform size are produced, hence there is no problem related to 
the encapsulant's viscosity at high concentrations, rather the only limitation is whether the material undergoes crosslinking or not (BOTREL et al., 2012; CHANG et al., 2014; MATALANIS et al., 2012; MISHRA et al., 2012; PAULA et al., 2012). To the best of the author's knowledge, there are no studies focusing on such a comparison. The efficiency of encapsulation and thermal stability of the samples were evaluated and a morphologic study of the microparticles was performed.

\section{MATERIALS AND METHODS}

\subsection{MATERIALS}

The orange (Citrus sinensis, L. Osbeck) essential oil (OEO) used as the raw material was purchased from Cutrale (Brazil). The wall agents applied in this study were: sodium alginate (SA) (Cargill, Brazil), maltodextrin DE 10 (MD) (Ingredion, Brazil) and sodium octenylsuccinate modified starch (SM) (National Starch, Brazil). The other materials used in this analysis were the non-ionic surfactant Tween 80 (TW) (Sigma-Aldrich, Brazil) and the crosslinking agent calcium chloride (CC) (Synth, Brazil).

Maltodextrin was used as an encapsulating material because it is a low cost and slightly hygroscopic material, has the ability to bind to aromatic compounds, presents low viscosity at high concentrations, forms a film protecting the volatile material, has antioxidant effect, and retain volatiles in the range of 80 to $100 \%$. As maltodextrin does not act as an emulsifier (it is hydrophilic and lipophilic), it is used in combination with modified starch to stabilize emulsions (BOTREL et al., 2015; CALISKAM and DIRIM, 2013; JOYE and McCLEMENTS, 2014). The starch chemically modified by partial hydrolysis followed of reaction with the hydrophobic component octenylsuccinate has good water solubility, retention of volatiles over $93 \%$, stabilizes emulsions and has low viscosity, however exerts little protection against oxidation during storage. Hence, it is important to use octenylsuccinate modified starch in association with maltodextrin (FERNANDES et al., 2014; MARQUES et al., 2014; SILVA et al., 2013; SINGH and DIXIT, 2014).

Alginate is an anionic polymer composed of linear chains of $\alpha$-L-glucuronic acid and $\beta-D-$ mannuronic acid, which form hydrogels, films, spheres, micro and nanoparticles in the presence of ions such as $\mathrm{Ca}^{++}$, and thus it has the capacity of encapsulating a number of substances, such as essential oils. Sodium alginate was used as an encapsulating material because it is slightly hygroscopic, has the ability to bind to aromatic compounds, it is low cost, forms a film protecting the volatile material, has antioxidant effect and retains volatiles in the range of 70 to $100 \%$. As the sodium alginate has high viscosity at high concentrations, it is not suitable for the encapsulation method by spray drying. Similarly, such as maltodextrin and modified starch do not undergo crosslinking as induced by $\mathrm{CaCl}_{2}$, they are not used in the coacervation method (DONG et al., 2013; MISHRA et al., 2012).

\subsection{METHODS}

\subsubsection{Microcapsules formation}

The methods used for obtaining the microparticles are shown in Table 1. Both formulations were performed in triplicate. Spray drying and coacervation used different encapsulating agents because of the particularities of each microencapsulation method. Sodium alginate forms a highly viscous solution when diluted, therefore it is not applicable to the microencapsulation by spray drying. Coacervation, by its turn, is a chemical method in which sodium alginate is cross-linked by calcium chloride ( $Q V$ et al., 2011). Although maltodextrin forms a film protecting the volatile material, providing antioxidant effect, it is not emulsifying, thus requires a combination with modified starch in order to stabilize emulsions. As modified starch presents high solubility in water, low viscosity and excellent retention of volatiles, it stabilizes the emulsion but offers low protection against oxidation 
during storage, therefore the importance of using starch associated with maltodextrin in the spray drying method (CHANG et al., 2014). The formulations as well as the process conditions for the spray-drying and coacervation methods were chosen based on results of pre-tests (data not shown).

TABLE 1 - METHODS FOR OBTAINING THE MICROPARTICLES.

\begin{tabular}{cccc}
\hline $\begin{array}{c}\text { Microencapsulation } \\
\text { method }\end{array}$ & Carrier & Crosslinking agent & Drying method \\
\hline Spray drying & Starch and maltodextrin & None & Spray drying $\left(150^{\circ} \mathrm{C}\right)$ \\
\hline Coacervation & Sodium alginate & $\mathrm{CaCl}_{2} 1 \%$ & Oven $\left(30^{\circ} \mathrm{C}\right)$ \\
\hline
\end{tabular}

For the encapsulation by spray drying, the mass ratio of the mixture consisting of maltodextrin (DE 10), modified starch and orange essential oil necessary to form an emulsion was 3.5: 1.0: 1.0, respectively (Table 2), taking into consideration the viscosity of these materials. Firstly, maltodextrin was homogenized with starch at $10.000 \mathrm{rpm}$ using a mixer (Silverson, model L4RT, England) during 40 minutes. The resulting mixture was added of orange essential oil and homogenized during 2 minutes also at $10.000 \mathrm{rpm}$. The total solids content of the dispersion was initially $56 \%(\mathrm{w} / \mathrm{w})$. The spray drying was carried out in a spray dryer (Labmaq, model MSD 1.0, Brazil) under the following conditions: nozzle diameter of $0.70 \mathrm{~mm}$, atomization pressure of 4.75

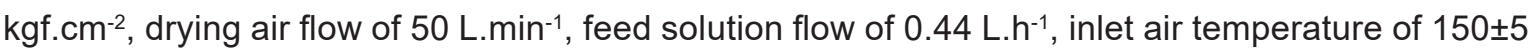
${ }^{\circ} \mathrm{C}$ and outlet air temperature of $80 \pm 5{ }^{\circ} \mathrm{C}$ (CHANG et al., 2014; SILVA et al., 2013; SINGH and DIXIT, 2014).

As mentioned previously, such conditions were chosen based on results of pre-tests (data not shown). All runs were performed in triplicate. The control samples were spray dried with all ingredients except for the essential oil. The final product was stored at room temperature.

For the encapsulation by coacervation, the mass ratio of the mixture of orange essential oil, sodium alginate and Tween 80 was 1.0: $0.14: 0.11$, respectively (Table 2). Sodium alginate and Tween 80 were homogenized during 40 minutes at $10.000 \mathrm{rpm}$ at room temperature. The resulting mixture was added of orange essential oil and homogenized during 2 minutes at 10.000 rpm (GONSALVES et al., 2009; LERTSUTTHIWONG et al., 2008; QV et al., 2011; SARAVANAN and RAO, 2010; SOLIMAN et al., 2013). The total solids content of the dispersion was $11 \%(\mathrm{w} / \mathrm{w})$ before coacervation. Tween 80 (polysorbate 80 ) was used to stabilize the oil-water emulsion prior to coacervation. Tween 80 was not used in the method of spray drying because in this case the modified starch provides encapsulating and surfactant effects, retaining the essential oil in the emulsion. The emulsion was sprinkled into $1 \mathrm{~L}$ of a $1 \%(\mathrm{w} / \mathrm{v})$ calcium chloride solution at a flow of $3.5 \mathrm{~mL}$. $\mathrm{min}^{-1}$ by using a peristaltic pump, a silicone hose and a needle with an aperture of $1.20 \mathrm{~mm}$ in order to reticulate the microparticles (methodology adapted from Gonsalves et al., 2009). The alginate microparticles were washed three times with distilled water for removing the residual Tween 80 and calcium chloride. After each washing, the samples were filtered for the removal of residual water. Then, the microparticles were dried in a convective oven at $30^{\circ} \mathrm{C}$ for $24 \mathrm{~h}$ (GONSALVES et al., 2009; LERTSUTTHIWONG et al., 2008). All runs were performed in triplicate. It is worth mentioning that in the encapsulation of flavors by spray drying, the typical ratio between encapsulating agent and encapsulated material is 4.5: 1. The high ratio of surface area/volume of the particles promotes rapid evaporation of water. Hence, the exposure of the particles to heat is short (typically a few seconds). Considering that the core temperature does not exceed $100^{\circ} \mathrm{C}$, the occurrence of undesirable changes in thermosensitive compounds is reduced, increasing retention of volatiles (ARARUNA et al., 2013; BOTREL et al., 2014). 
TABLE 2 - EXPERIMENTAL DESIGN FOR FORMULATION OF THE MICROPARTICLES.

\begin{tabular}{cccccc}
\hline \multirow{2}{*}{$\begin{array}{c}\text { Microencapsulation } \\
\text { method }\end{array}$} & \multicolumn{5}{c}{ Ingredient } \\
\cline { 2 - 6 } & Maltodextrin & Modified starch & Essential oil & Sodium alginate & Tween 80 \\
\hline Spray drying & 3.50 & 1.00 & 1.00 & --- & -- \\
\hline Coacervation & --- & --- & 1.00 & 0.14 & 0.11 \\
\hline
\end{tabular}

\subsubsection{Morphology and mean diameter of the microparticles}

Micrographs were obtained by using a scanning electron microscope (Jeol, model JSM $6360 \mathrm{LV}, \mathrm{Brazil}$ ) with an accelerating voltage of $15 \mathrm{kV}$. The microparticles were fixed in an aluminum support and then submitted to metallization with $350 \AA$ thick gold under vacuum using the equipment Balzers Sputtering SCD-030. The samples were observed at various magnitudes (from 30x to 1500x). Such micrographs reveal data from internal and external morphology, porosity and average size of the microparticles.

For the analysis of size distribution of the granules, $5 \mathrm{~g}$ of microparticles containing orange essential oil and the control samples (without OEO) were homogenized with distilled water by ultrasound for 60 seconds. Afterwards, the solution turbidity was measured with a laser particle size analyzer (model CILAS 1064, CILAS, France). The determination interval ranged from $0.02 \mu \mathrm{m}$ to $2000 \mu \mathrm{m}$.

\subsubsection{Thermogravimetric analysis (TGA)}

The thermogravimetric curves were obtained with a thermogravimetric scale (Shimadzu ${ }^{\circledR}$, model TGA-60, Japan) under the following conditions: samples of $5.0 \mathrm{mg}$, synthetic air as the chamber atmosphere, gas flow of $100 \mathrm{~mL} / \mathrm{min}$, heating rate of $10^{\circ} \mathrm{C} / \mathrm{min}$ and temperature range between 30 ${ }^{\circ} \mathrm{C}$ and $600{ }^{\circ} \mathrm{C}$ (AGARWALL and DOLLIMORE, 1998; HIJO et al., 2015). The decomposition of the essential oil is revealed through the thermogravimetric curves: microencapsulation renders increased thermal stability to the product if the pure essential oil has a lower decomposition temperature compared to the microencapsulated one.

\subsubsection{Differential Scanning Calorimetry (DSC)}

The Differential Scanning Calorimetry (DSC) curves, which indicates the temperature in which thermal events either endothermic and exothermic occur, were obtained by using a calorimeter (Shimadzu ${ }^{\circledR}$, model DSC-60, Japan) standardized with a pure $(99.99 \%)$ indium standard (IONASHIRO E GIOLITO, 2005). Before determination, an empty micro crucible identical to that used in the analyses was placed inside the calorimeter (HIJO et al., 2015) for a previous test. The assay conditions were: sample's weight of $2.0 \mathrm{mg}$, synthetic air as the chamber atmosphere, gas flow of $100 \mathrm{~mL} / \mathrm{min}$, heating rate of $10^{\circ} \mathrm{C} / \mathrm{min}$ and temperature range between $30^{\circ} \mathrm{C}$ and $250{ }^{\circ} \mathrm{C}$.

\subsubsection{Encapsulation efficiency}

Due to the high volatility of the oil, it was not possible to quantify encapsulation efficiency by assessing the mass of oil on the particles' surface. Alternatively, a headspace extraction technique was developed to quantify the microencapsulated essential oil. The analyses were performed in an extractor (Leap, model CTC Combi Pal, USA) coupled to a gas chromatograph (Varian, model GC-450, Netherlands) provided with a mass spectrometer detector. Samples of $1 \mathrm{~g}$ were placed in a $20 \mathrm{~mL}$ vial containing $2.4 \mathrm{~g}$ of ethanol. The sample and the syringe temperature were $35^{\circ} \mathrm{C}$, the incubation period was 10 minutes and the stirring was performed at $500 \mathrm{rpm}$ each 20 seconds. 
The identification of the orange oil compounds before and after encapsulation was conducted by comparing the retention times of the standard orange essential oil and the samples using gas chromatography and also by evaluating the mass spectra of the samples with the aid of a NIST (National Institute of Standards and Technology) spectra data bank. The orange essential oil was characterized by gas chromatography/mass spectrometry (GS/MS) by using a gas chromatograph (Varian, model Saturn Ion Trap 2000 with CP 3800, Netherlands), which provided the mass spectra of the compounds (BENELLI et al., 2010; TOVAR, 2010). The injection temperature and volume were $250{ }^{\circ} \mathrm{C}$ (split ratio $1: 300$ ) and $0.5 \mu \mathrm{L}$, respectively. The column used was a CP-SIL8CB fused silica column supplied by Chrompack $(0.25 \mathrm{~mm}$ of internal diameter, $30 \mathrm{~mm}$ of length and $0.25 \mu \mathrm{m}$ of liquid film). Helium was used as a carrier gas at a flow of $1.0 \mathrm{~mL} / \mathrm{min}$. The column temperature ranged from $40{ }^{\circ} \mathrm{C}$ to $300{ }^{\circ} \mathrm{C}\left(20^{\circ} \mathrm{C} / \mathrm{min}\right)$ and remained for $45 \mathrm{~min}$ at $300^{\circ} \mathrm{C}$.

\subsubsection{Statistical analysis}

The results for quantification of the main components of the orange essential oil and encapsulation efficiency for the microparticles were statistically analyzed by the Tukey test using the software Statistica (StatSoft, USA). Differences between means within a $95 \%$ confidence interval $(p<0.05)$ were considered significant.

\section{RESULTS AND DISCUSSION}

\subsection{MORPHOLOGY AND MEAN DIAMETER OF THE MICROPARTICLES}

The internal and external morphology, porosity and average size of the microparticles were evaluated by Scanning Electron Microscopy. The microparticles obtained by the two methods studied, i.e. spray drying and coacervation, did not present cavities or cracks on the surface, as observed in Figures 1 and 2. The absence of cavities indicates that a continuous film was formed in the external part of the microparticles, suggesting a high encapsulation efficiency (LEIMANN et al., 2009).

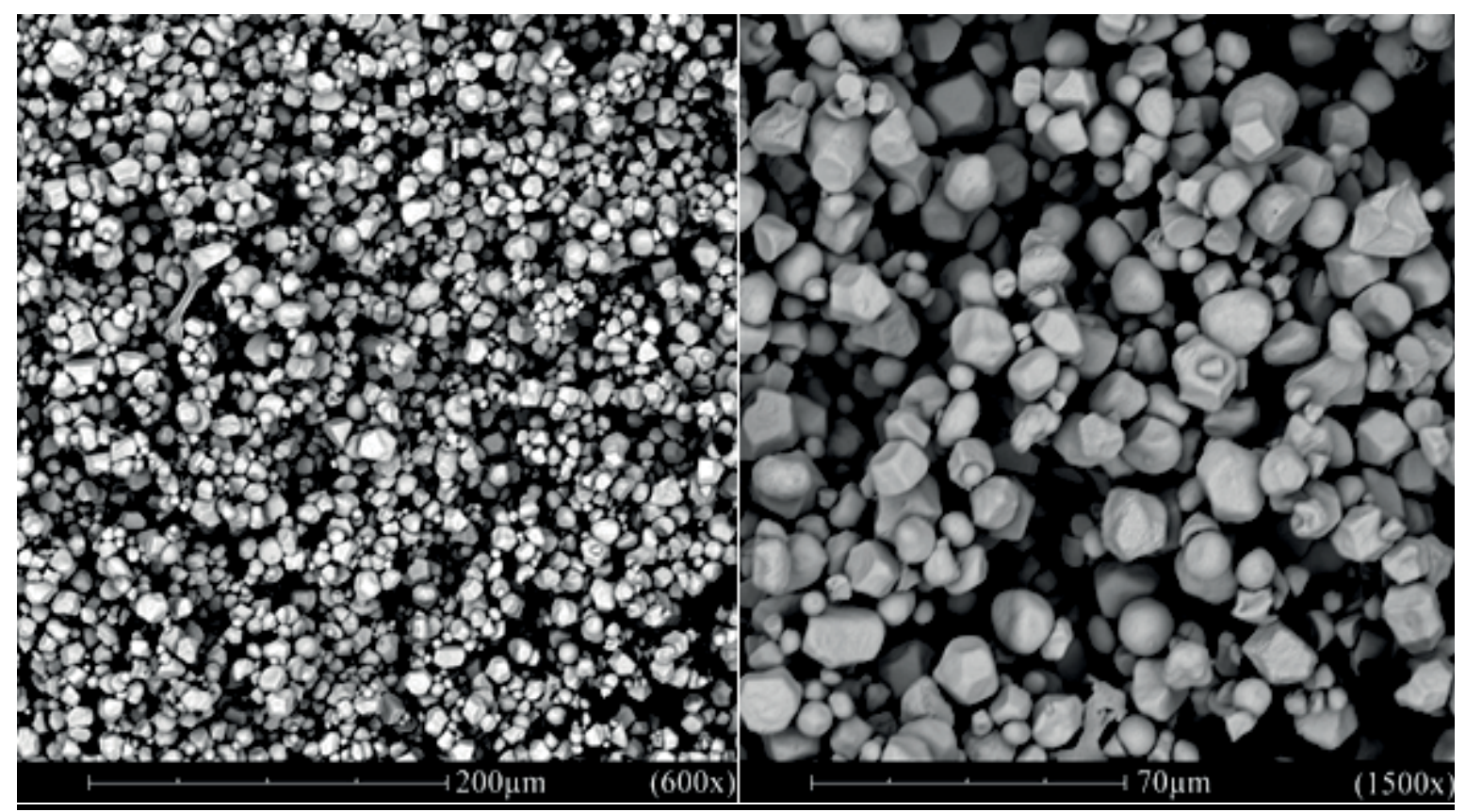

FIGURE 1 - MORPHOLOGICAL ASPECTS OF THE MICROPARTICLES CONTAINING ORANGE ESSENTIAL OIL, MODIFIED STARCH AND MALTODEXTRIN OBTAINED BY SPRAY DRYING: (A) 600X AND (B) 1500X. 


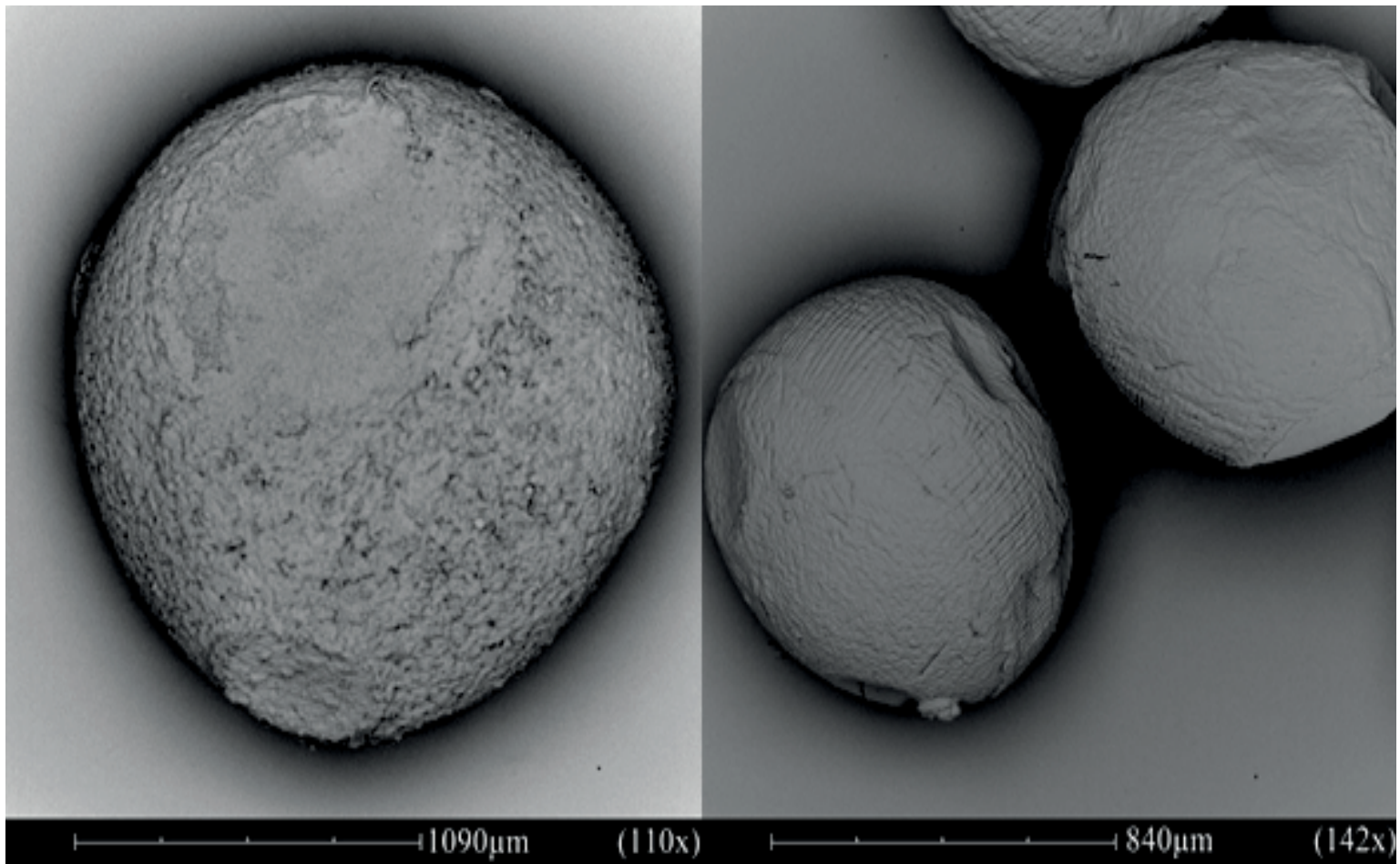

\section{FIGURE 2 - MORPHOLOGICAL ASPECTS OF THE MICROPARTICLES CONTAINING ORANGE ESSENTIAL OIL AND SODIUM ALGINATE OBTAINED BY COACERVATION: (A) 110X AND (B) 142X.}

Figures 3 and 4 illustrate the morphology of the internal portion of the microparticles obtained by spray drying and coacervation, respectively, which evidence the presence of pores. The porous structure observed indicates a possible presence of essential oil, suggesting that it was successfully encapsulated inside the microsphere. In such samples, amplifications of 30x and 1500x were used to yield the image of the transverse section of the microparticles.

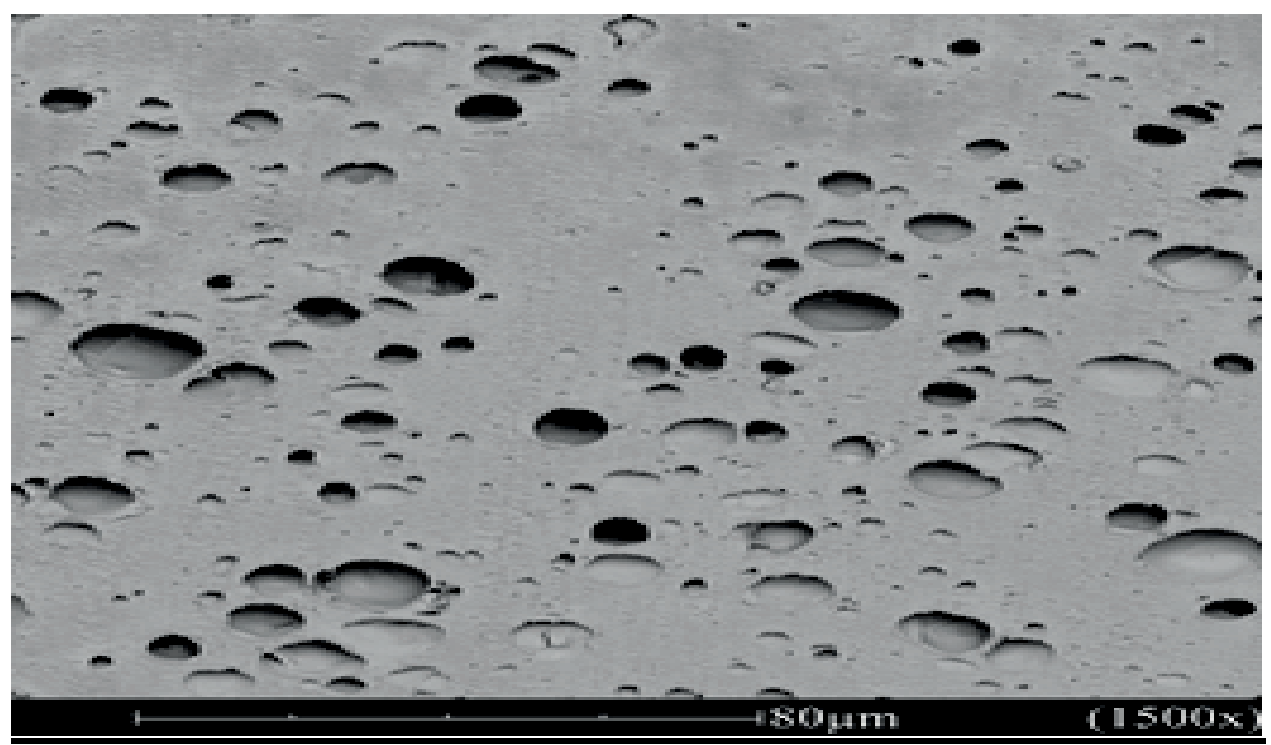

FIGURE 3 - MORPHOLOGICAL ASPECTS OF THE INTERNAL FACE OF THE MICROPARTICLES CONTAINING ORANGE ESSENTIAL OIL, MALTODEXTRIN AND MODIFIED STARCH OBTAINED BY SPRAY DRYING (1500X). 


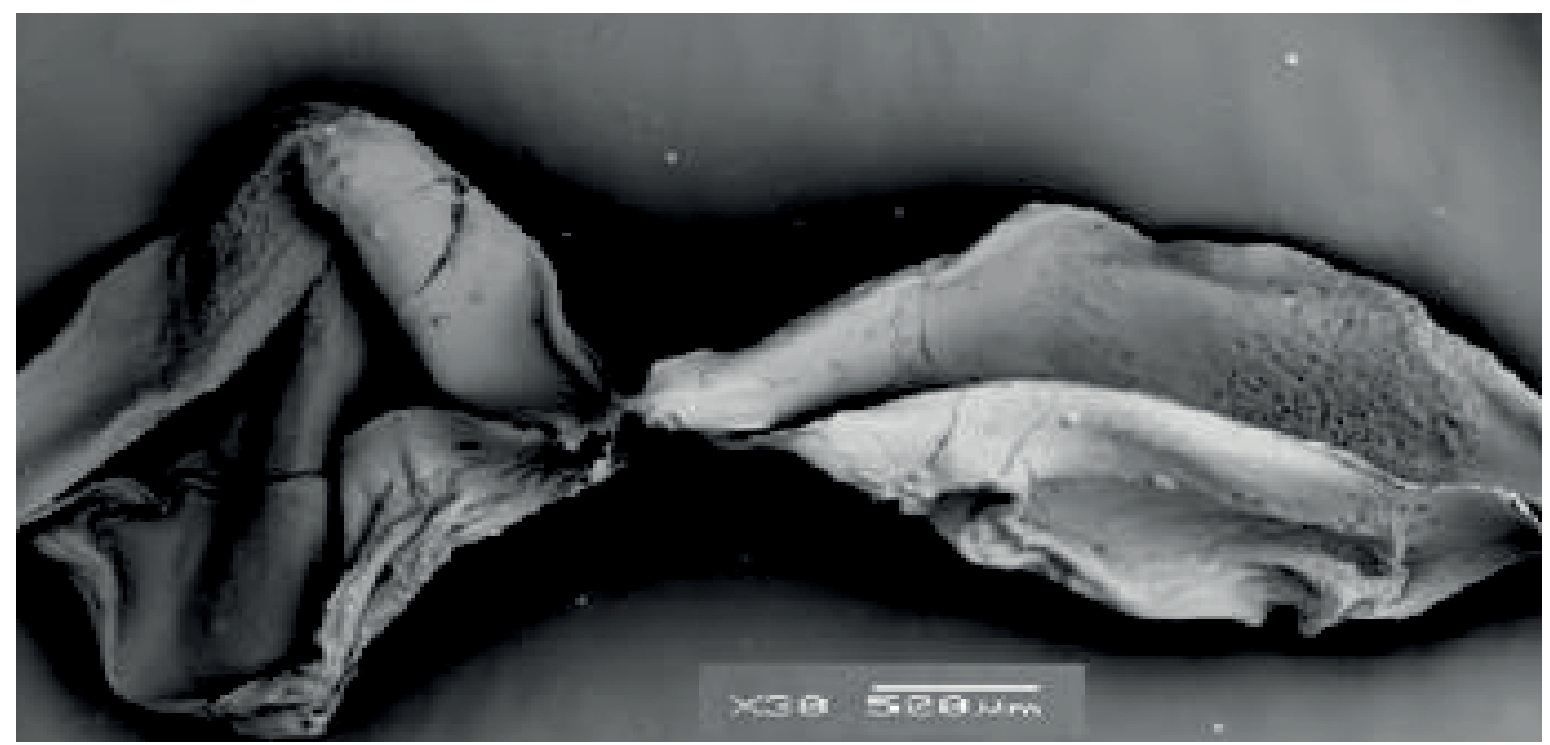

FIGURE 4 - MORPHOLOGICAL ASPECTS OF THE INTERNAL FACE OF THE MICROPARTICLES CONTAINING ORANGE ESSENTIAL OIL AND SODIUM ALGINATE OBTAINED BY COACERVATION (30X).

The laser granulometric analysis revealed a satisfactory size distribution according to Table 3. The particle dimensions were larger for the coacervated oil when compared to the spray dried one. According to Ré (2006), it is expected to obtain samples with average regular size when the spray drying conditions, such as airflow, air temperature and sample flow rate, are kept constant. Although a good uniformity was indeed obtained for the spray dried particles, the coacervated ones are more uniform, that is, they presented a more homogeneous size distribution.

The particle size distribution of the samples is shown in Table 3: The maximum diameter of the microparticles $-\mathrm{d}(0.1 \mu \mathrm{m}), \mathrm{d}(0.5 \mu \mathrm{M})$ and $\mathrm{d}(0.9 \mu \mathrm{M})$ - are presented by $10 \%, 50 \%$ and $90 \%$ of the samples, respectively. The microparticles obtained by coacervation are greater because the nozzle diameter of the peristaltic pump is larger than the diameter of the spray dryer atomizer. The microparticles obtained by spray drying had a mean volume diameter of $1.02 \mu \mathrm{m}$ and particle size ranging from 0.31 to $1.89 \mu \mathrm{m}$, while the coacervated microparticles had a mean volume diameter of $908.63 \mu \mathrm{m}$ and particle size varying from 346.37 to $1867.31 \mu \mathrm{m}$ (Table 3).

\section{TABLE 3 - GRANULOMETRIC PARAMETERS OF THE MICROPARTICLES OBTAINED BY} SPRAY-DRYING AND COACERVATION.

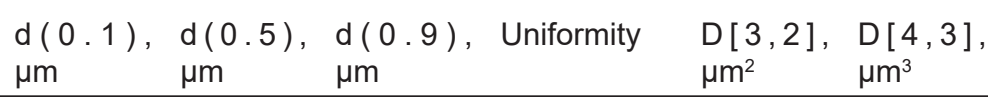

$48 \quad 1$

${ }^{*} d(0.1), d(0.5)$ and $d(0.9)$ are the maximum diameters $(\mu \mathrm{m})$ presented by $10 \%, 50 \%$ and $90 \%$, respectively, of the sample's granulometric distribution;

*Uniformity is the absolute deviation in relation to the median;

$\mathrm{D}[3,2]$ or Sauter mean diameter (mean surface of the particles);

$\mathrm{D}[4,3]$ or Brouckere mean diameter (volume mean diameter of the particles). 


\subsection{THERMOGRAVIMETRIC ANALYSIS (TGA) AND DIFFERENTIAL \\ SCANNING CALORIMETRY (DSC)}

The thermogravimetric analysis (Table 4; Figure 5, 6, 7, 8 and 9) used to assess the thermal stability of the samples showed that there was one single step of mass loss of $90 \%$, which corresponds to the volatilization of pure essential oil occurred between $32^{\circ} \mathrm{C}$ and $101^{\circ} \mathrm{C}$. The temperature corresponding to the beginning of degradation increased when compared to that of the pure OEO, suggesting an increase in the thermal stability of the encapsulated OEO from $32{ }^{\circ} \mathrm{C}$ to $206{ }^{\circ} \mathrm{C}$. These results are similar to those obtained by Marreto et al. (2008). The modified starch/maltodextrin microparticles obtained by spray drying presented $88 \%$ of mass loss. A particular event was observed in the thermograms for both methods between 30 ${ }^{\circ} \mathrm{C}$ and $200{ }^{\circ} \mathrm{C}$, that is, the microparticles experienced a mass loss of $10 \%$ between these temperatures $(\Delta \mathrm{m}=10 \%)$, which can be ascribed to the elimination of moisture from the samples. The alginate microparticles obtained by coacervation, by its turn, presented $45 \%$ of mass loss. The lower mass loss of the coacervated microparticles may be ascribed to the cross-linked sodium alginate, which degrades in a longer time than maltodextrin and modified starch. Probably these microspheres take longer to release the essential oil. Despite of these differences, the microcapsules obtained either by spray drying or coacervation showed good encapsulation efficiency and increased the thermal stability of the encapsulated material respect to the pure OEO.

\section{TABLE 4 - THERMOGRAVIMETRIC PARAMETERS OF PURE ESSENTIAL OIL AND OF MICROPARTICLES OBTAINED BY SPRAY-DRYING AND BY COACERVATION WITH AND WITHOUT ORANGE ESSENTIAL OIL.}

\begin{tabular}{|c|c|c|c|c|c|c|c|c|c|c|c|c|}
\hline \multirow[b]{2}{*}{ Sample } & \multicolumn{3}{|c|}{ 1st thermal event } & \multicolumn{3}{|c|}{ 2nd thermal event } & \multicolumn{3}{|c|}{ 3rd thermal event } & \multicolumn{3}{|c|}{ 4th thermal event } \\
\hline & $\begin{array}{c}\Delta_{\text {temp }} \\
\left({ }^{\circ} \mathrm{C}\right)\end{array}$ & $T_{p}$ DTA & $\begin{array}{r}\Delta_{\text {mass }} \\
(\%)\end{array}$ & $\begin{array}{l}\Delta_{\text {temp }} \\
\quad\left({ }^{\circ} \mathrm{C}\right)\end{array}$ & $T_{p}^{D T A}$ & $\begin{array}{r}\Delta_{\text {mass }} \\
(\%)\end{array}$ & $\begin{array}{c}\Delta_{\text {temp }} \\
\left({ }^{\circ} \mathrm{C}\right)\end{array}$ & $T_{p}{ }^{D T A}$ & $\begin{array}{r}\Delta_{\text {mass }} \\
(\%)\end{array}$ & $\begin{array}{c}\Delta_{\text {temp }} \\
\left({ }^{\circ} \mathrm{C}\right)\end{array}$ & $\mathrm{T}_{\mathrm{p}}^{\mathrm{DTA}}$ & $\begin{array}{r}\Delta_{\text {mass }} \\
(\%)\end{array}$ \\
\hline OEO & $\begin{array}{l}30- \\
100\end{array}$ & 100 & 99 & & & & & & & & & \\
\hline $\begin{array}{r}\text { MP } \\
\text { spray } \\
\text { OEO }\end{array}$ & $\begin{array}{c}30- \\
100\end{array}$ & 66 & 10 & $\begin{array}{r}208 \\
-435\end{array}$ & 352 & 75 & $\begin{array}{r}435 \\
-496\end{array}$ & 480 & 15 & & & \\
\hline $\begin{array}{c}\text { MP } \\
\text { spray } \\
\text { control }\end{array}$ & $\begin{array}{l}30- \\
100\end{array}$ & 91 & 10 & $\begin{array}{r}208 \\
-435\end{array}$ & 362 & 75 & $\begin{array}{r}435 \\
-496\end{array}$ & 478 & 15 & & & \\
\hline $\begin{array}{c}\text { MP } \\
\text { coac OEO }\end{array}$ & $\begin{array}{l}30- \\
100\end{array}$ & 69 & 6 & $\begin{array}{r}100 \\
-290\end{array}$ & 280 & 32 & $\begin{array}{r}290 \\
-500\end{array}$ & 492 & 34 & $\begin{array}{r}500 \\
-600\end{array}$ & 587 & 9 \\
\hline $\begin{array}{c}\text { MP } \\
\text { coac } \\
\text { control }\end{array}$ & $\begin{array}{l}30- \\
100\end{array}$ & 85 & 3 & $\begin{array}{r}108 \\
-209\end{array}$ & 209 & 5 & $\begin{array}{r}209 \\
-437\end{array}$ & 284 & 41 & $\begin{array}{r}437 \\
-541\end{array}$ & 514 & 51 \\
\hline $\begin{array}{l}\text { DTA }=\text { tempe } \\
\text { oparticles o } \\
\text { ying (no ora } \\
\text { ontol = contr } \\
\text { Ss in this the }\end{array}$ & e of th & $\begin{array}{l}\text { Il oil); } \\
\text { les o }\end{array}$ & $\begin{array}{l}\text { he diffe } \\
\text { hg with }\end{array}$ & tial the & $\begin{array}{l}\text { nal ana } \\
\text { ential o } \\
\text { oparticl } \\
\text { n (no o }\end{array}$ & $\begin{array}{l}\text { sis (DTA } \\
\text { MP spr } \\
\text { obtaine } \\
\text { ange ess }\end{array}$ & $\begin{array}{l}\text {; OEO } \\
\text { y contrc } \\
\text { by coa } \\
\text { ential oil }\end{array}$ & $\begin{array}{l}\text { orange } \\
=\text { contr } \\
\text { rvation } \\
\Delta_{\text {temp }}=\end{array}$ & $\begin{array}{l}\text { ssentia } \\
\text { microp } \\
\text { vith ora } \\
\text { mperat }\end{array}$ & $\begin{array}{l}\text { oil; MP } \\
\text { rticles } \\
\text { ge ess } \\
\text { re varis }\end{array}$ & $\begin{array}{l}\text { pray O } \\
\text { tained } \\
\text { tial oil; } \\
\text { on; } \Delta_{\text {mas }}\end{array}$ & $\begin{array}{l}\text { O = mi } \\
\text { y spra } \\
\text { MP coa } \\
=\text { mas }\end{array}$ \\
\hline
\end{tabular}




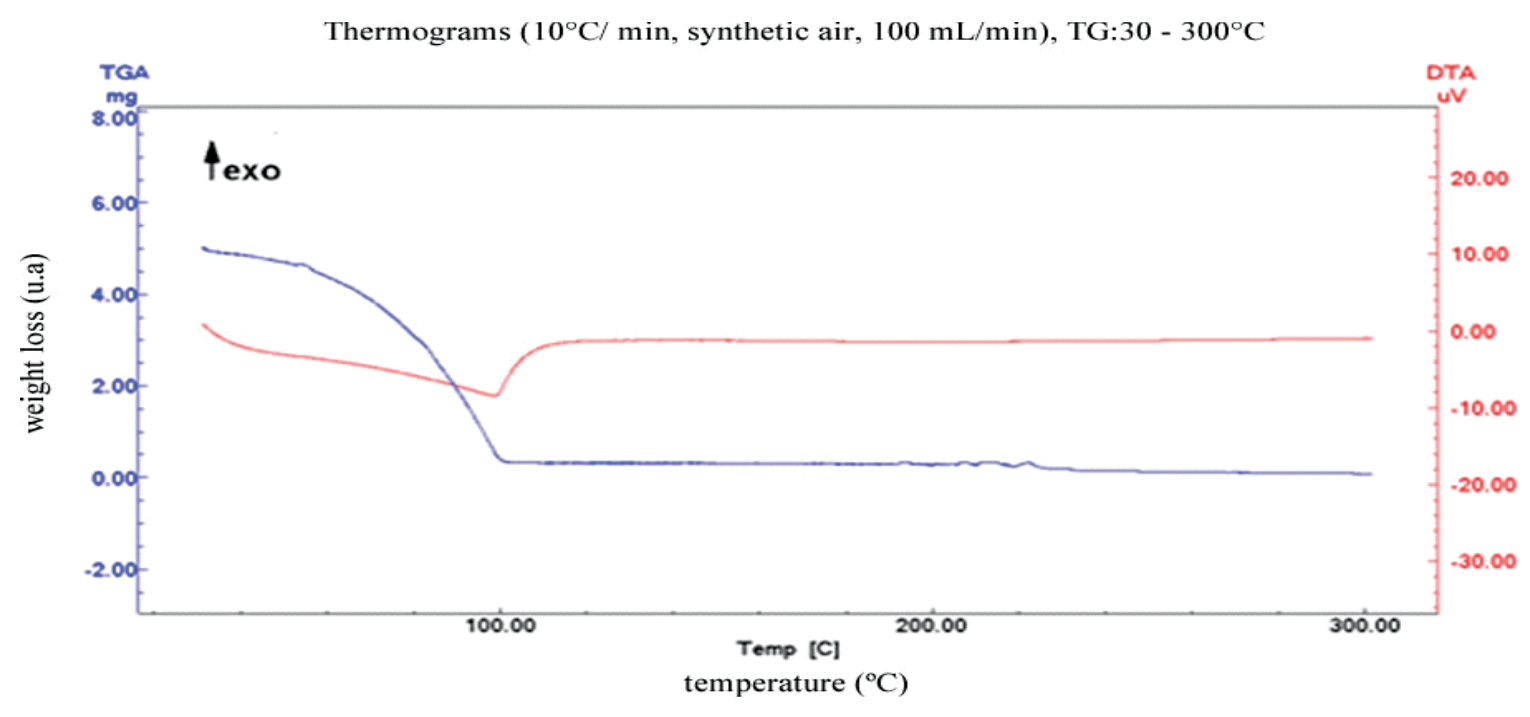

FIGURE 5 - THERMOGRAVIMETRIC ANALYSIS FOR THE PURE ORANGE ESSENTIAL OIL.

Thermograms $\left(10^{\circ} \mathrm{C} / \mathrm{min}\right.$, synthetic air, $\left.100 \mathrm{~mL} / \mathrm{min}\right), \mathrm{TG}: 30-300^{\circ} \mathrm{C}$

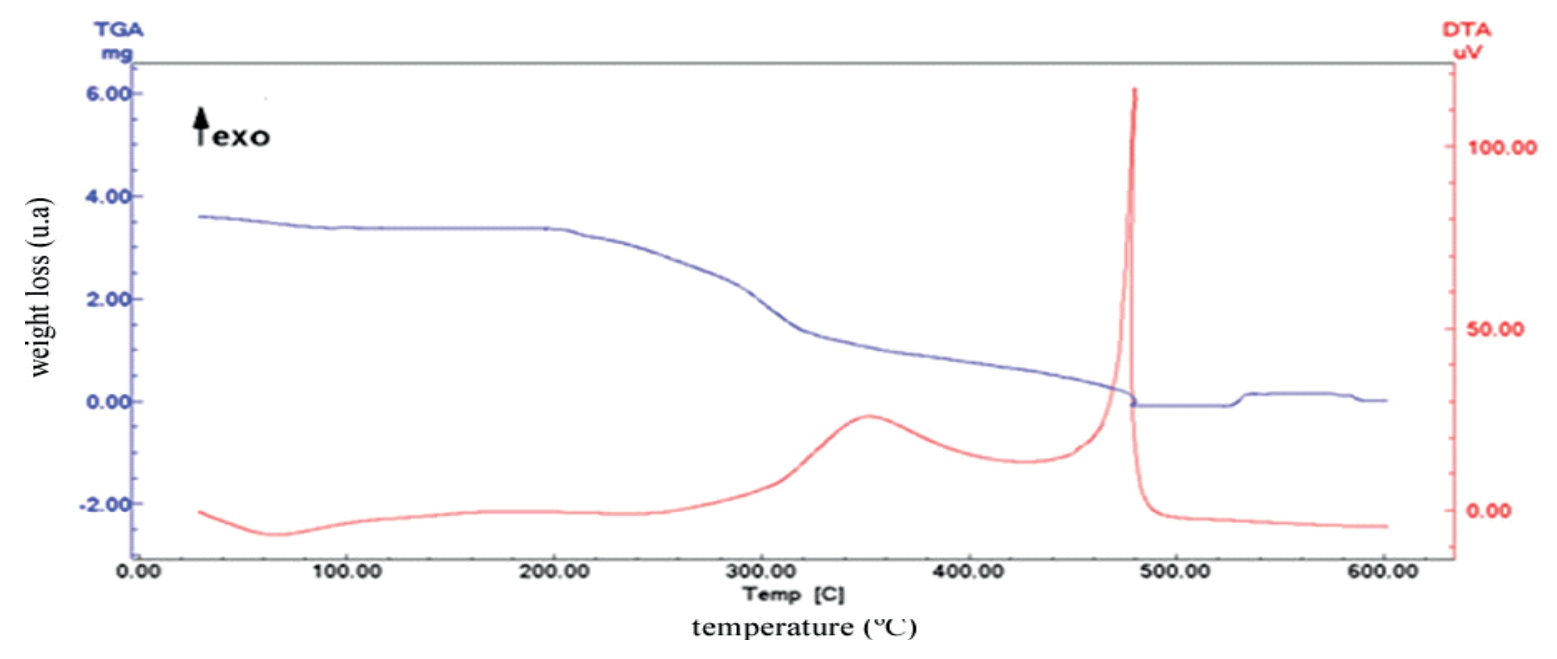

FIGURE 6 - THERMOGRAVIMETRIC ANALYSIS FOR THE MICROPARTICLES WITH ORANGE ESSENTIAL OIL OBTAINED BY SPRAY DRYING.

Thermograms $\left(10^{\circ} \mathrm{C} / \mathrm{min}\right.$, synthetic air, $\left.100 \mathrm{~mL} / \mathrm{min}\right), \mathrm{TG}: 30-300^{\circ} \mathrm{C}$

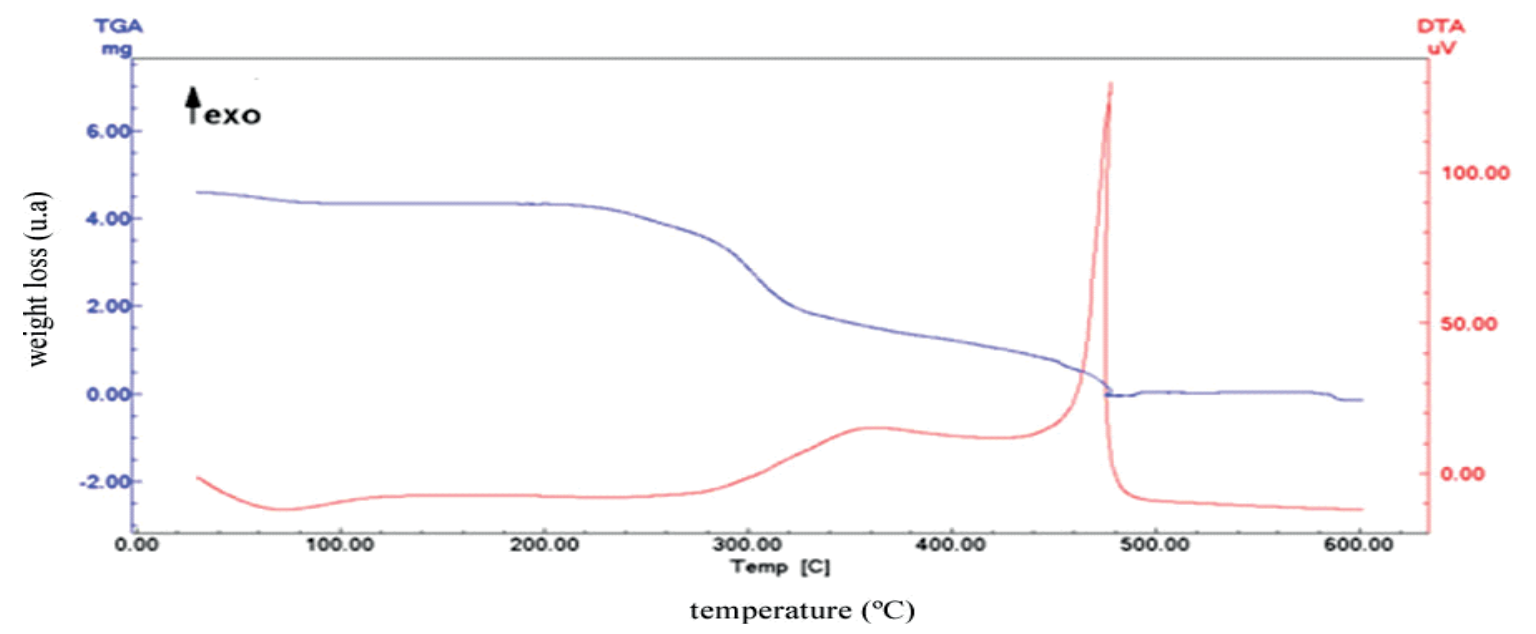

FIGURE 7 - THERMOGRAVIMETRIC ANALYSIS FOR THE CONTROL MICROPARTICLES OBTAINED BY SPRAY DRYING. 
Thermograms $\left(10^{\circ} \mathrm{C} / \mathrm{min}\right.$, synthetic air, $\left.100 \mathrm{~mL} / \mathrm{min}\right), \mathrm{TG}: 30-300^{\circ} \mathrm{C}$

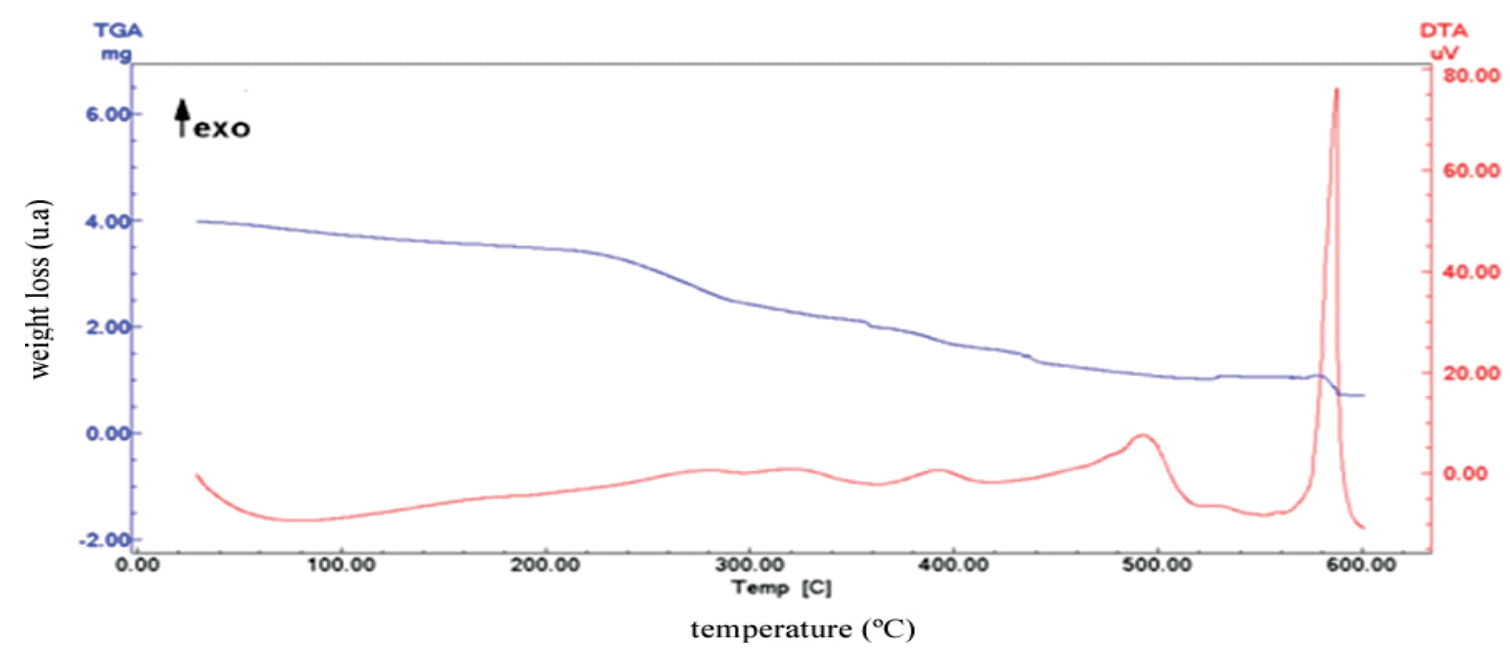

FIGURE 8 - THERMOGRAVIMETRIC ANALYSIS FOR THE MICROPARTICLES WITH ORANGE ESSENTIAL OIL OBTAINED BY COACERVATION.

Thermograms $\left(10^{\circ} \mathrm{C} / \mathrm{min}\right.$, synthetic air, $\left.100 \mathrm{~mL} / \mathrm{min}\right), \mathrm{TG}: 30-300^{\circ} \mathrm{C}$

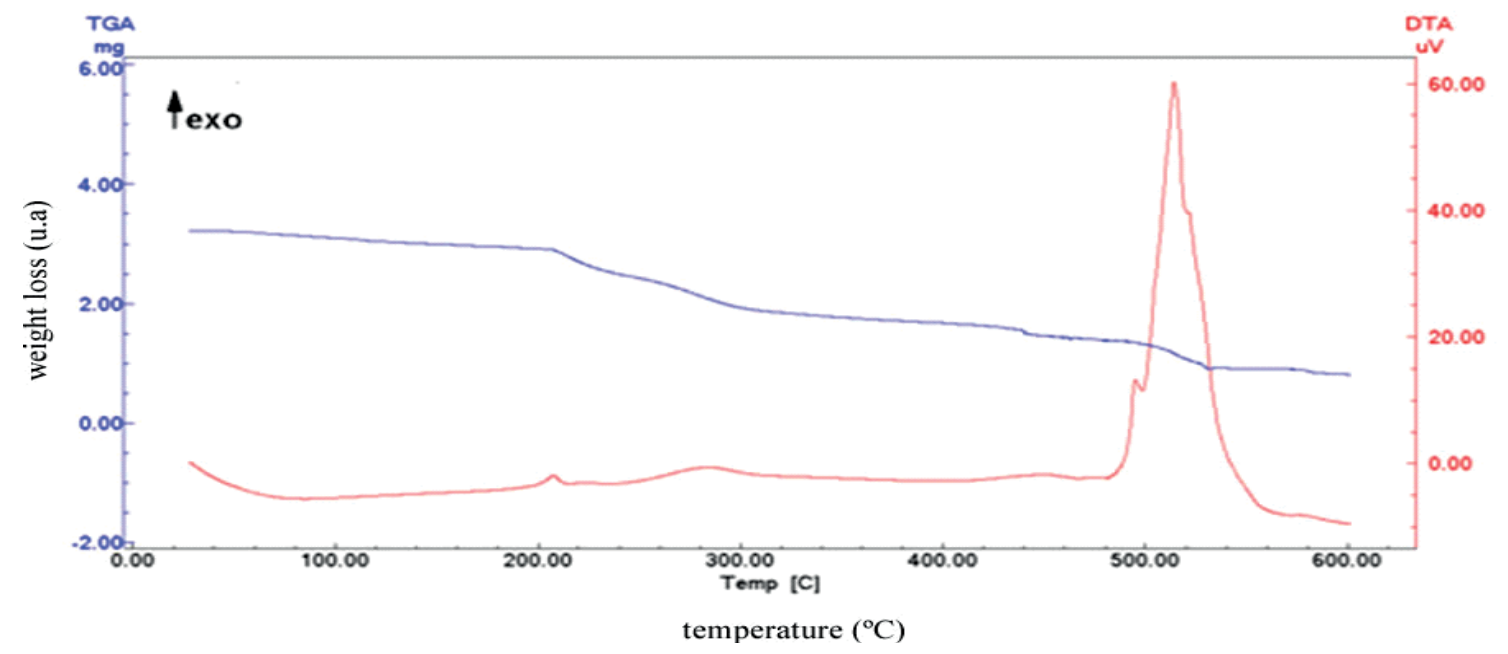

FIGURE 9 - THERMOGRAVIMETRIC ANALYSIS FOR THE CONTROL MICROPARTICLES OBTAINED BY COACERVATION.

FIGURE 10 - DIFFERENTIAL SCANNING CALORIMETRY FOR THE MICROPARTICLES OBTAINED BY COACERVATION AND SPRAY DRYING AND THE CONTROL SAMPLES. 
There was a remarkable difference in the thermal behavior of the microparticles containing orange essential oil when compared to the control samples (Figure 10). An incorporation above $90 \%$ of essential oil was observed for the microparticles. Since the endothermic peaks are dislocated when comparing the microparticles containing essential oil to the control samples, it is possible to infer that the microencapsulation promoted an interaction between the carrier polymers and the essential oil (MARRETO et al., 2008). Another remarkable behavior is the effect of reticulation on the system, which led to the formation of a new polymeric net. Thus, the oil was internally retained, yielding different DSC curves. Once again, this behavior suggests a successful interaction between polymer and oil (DONG and BODMEIER, 2006; YU and CHRISTIE, 2001).

It is important to mention that as a consequence of the encapsulation method and the wall materials used, microcapsules and microspheres were obtained by coacervation and spray drying, respectively, as shown in Figure 11. Microcapsules are characterized by presenting a core containing the active material surrounded by a membrane of wall agent, while microspheres are multinucleated polymeric matrix systems. Morphological assessment of microparticles can be performed by optical microscopy, scanning electron microscopy (SEM) and transmission electron microscopy (TEM) (SCHAFFAZICK et al., 2006). These microscopy techniques aim at evaluating the shape and size of the systems, making possible to differentiate microcapsules from microspheres (MOSQUEIRA et al., 2000), as well as to infer data on the type of surface of the microparticles (WANG et al., 2009). Because they are crosslinked, the coacervated microparticles protected more efficiently the essential oil encapsulated due to the presence of the outer layer, resulting in a higher thermal stability for the product respect to the spray dried particles. The TGA analysis allowed to verify that the coacervated microparticles degraded approximately $48 \%$ until $524{ }^{\circ} \mathrm{C}$ while the spray-dried microparticles degraded $88 \%$ until $500{ }^{\circ} \mathrm{C}$. In fact, the DSC analysis revealed that the essential oil microencapsulated by coacervation presented higher boiling point respect to the pure essential oil and the OEL encapsulated by spray drying.
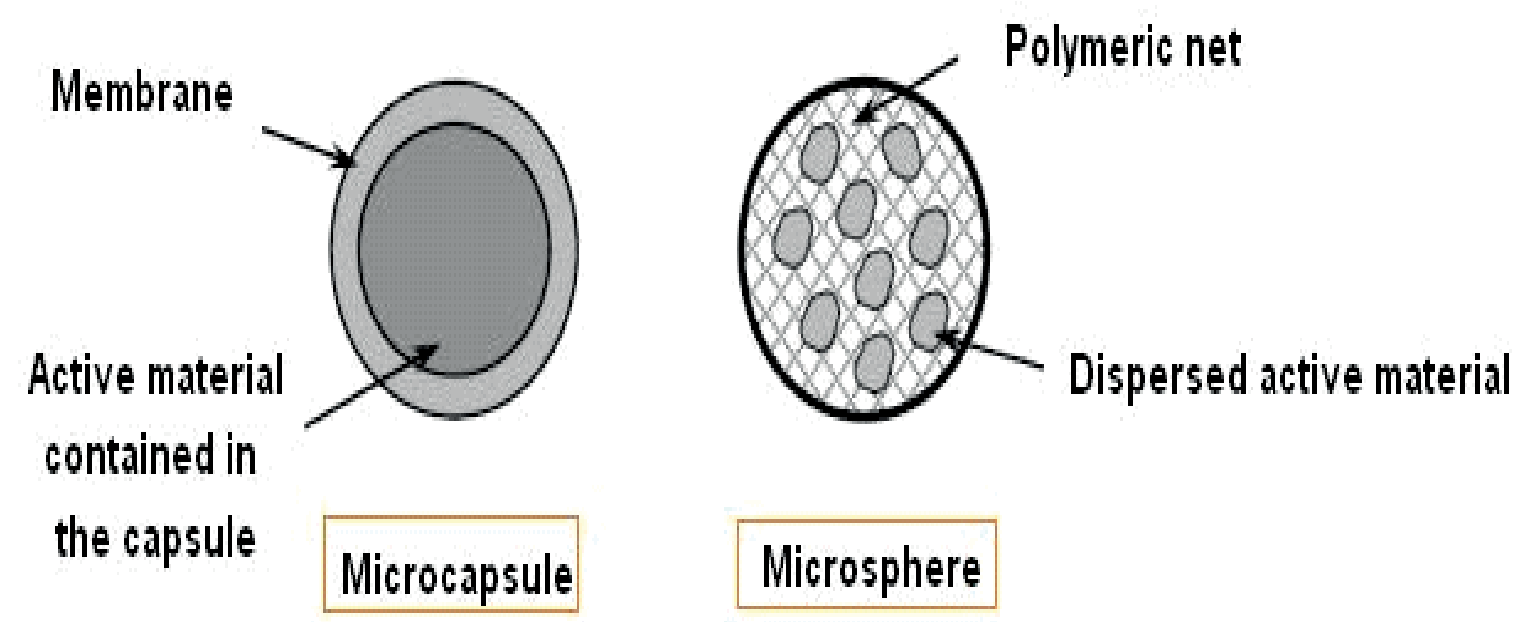

\section{FIGURE 11 - MORPHOLOGY OF MICROPARTICLES OBTAINED BY DIFFERENT ENCAPSULATION METHODS.}

\subsection{ENCAPSULATION EFFICIENCY}

After formed and dried, the microcapsules were analyzed by gas chromatography for quantifying the orange essential oil. The percentage of its main components are shown in Table 5 along with data on the same matter reported by Bertolini, Siani and Grosso, 2001. 
TABLE 5 - QUANTIFICATION (MASS PERCENTAGE) OF THE MAIN COMPONENTS OF THE ORANGE ESSENTIAL OIL.

\begin{tabular}{|c|c|c|c|c|}
\hline \multirow[b]{2}{*}{ Component } & \multicolumn{4}{|c|}{ Mass percentage $\%$} \\
\hline & $\begin{array}{c}\text { Reported by } \\
\text { Bertolini (2001) }\end{array}$ & $\begin{array}{c}\text { Before } \\
\text { encapsulation } \\
\pm \text { SD }\end{array}$ & $\begin{array}{c}\text { After } \\
\text { Coacervation } \\
\pm \text { SD }\end{array}$ & $\begin{array}{l}\text { After } \\
\text { spray-drying } \\
\pm S D\end{array}$ \\
\hline Ethanol & $0.100 \%$ & $N Q$ & $N Q$ & $N Q$ \\
\hline Ethyl Acetate & $0.005 \%$ & $N Q$ & $N Q$ & $N Q$ \\
\hline Acetal & $0.002 \%$ & $N Q$ & $N Q$ & $N Q$ \\
\hline Hexanal & $0.020 \%$ & $\mathrm{NQ}$ & $\mathrm{NQ}$ & $N Q$ \\
\hline Acetate Butyrate & $0.100 \%$ & $\mathrm{NQ}$ & $N Q$ & $N Q$ \\
\hline Trans-2-hexenal & $0 . .005 \%$ & $\mathrm{NQ}$ & $N Q$ & $N Q$ \\
\hline Alpha-pinene & $0.400 \%$ & $0.447 \pm 0.003 \%^{a}$ & $0.339 \pm 0.002 \%^{b}$ & $0.331 \pm 0.003 \%^{b}$ \\
\hline Beta-pinene & $N Q$ & $0.461 \pm 0.007 \%^{a}$ & $0.360 \pm 0.008 \%{ }^{b}$ & $0.356 \pm 0.005 \%^{b}$ \\
\hline $\begin{array}{c}\text { Trans- } \\
\text { isolimonene }\end{array}$ & $N Q$ & $0.046 \pm 0.001 \%$ a & $0.046 \pm 0.003 \%$ a & $0.032 \pm 0.001 \%^{b}$ \\
\hline Sabinene & $0.400 \%$ & $N Q$ & $N Q$ & $N Q$ \\
\hline Mircene & $1.800 \%$ & $1.767 \pm 0.011 \%^{a}$ & $1.651 \pm 0.007 \%^{\mathrm{b}}$ & $1.672 \pm 0.006 \%^{\mathrm{b}}$ \\
\hline Octanal & $0.500 \%$ & $0.291 \pm 0.003 \%^{a}$ & $0.289 \pm 0.005 \% \%^{a}$ & $0.288 \pm 0.002 \%^{a}$ \\
\hline $\begin{array}{l}\text { Pseudo- } \\
\text { limonene }\end{array}$ & $N Q$ & $0.087 \pm 0.001 \%$ & $0.087 \pm 0.001 \%$ & $0.078 \pm 0.002 \%$ b \\
\hline D-limonene & $93.600 \%$ & $95.930 \pm 0.013 \%^{a}$ & $95.781 \pm 0.009 \%^{\mathrm{b}}$ & $95.622 \pm 0.003 \%$ ' \\
\hline Linalol & $0.500 \%$ & $0.325 \pm 0.012 \%^{a}$ & $0.324 \pm 0.013 \%^{a}$ & $0.308 \pm 0.009 \%^{b}$ \\
\hline Alpha-terpineol & $N Q$ & $0.048 \pm 0.001 \%$ & $0.039 \pm 0.001 \%$ b & $0.041 \pm 0.002 \%^{b}$ \\
\hline Decanal & $0.600 \%$ & $N Q$ & $N Q$ & $N Q$ \\
\hline 1-dodecene & $N Q$ & $0.265 \pm 0.006 \%{ }^{a}$ & $0.265 \pm 0.004 \%{ }^{a}$ & $0.258 \pm 0.003 \%^{a}$ \\
\hline Neral & $0.200 \%$ & $0.229 \pm 0.004 \%^{a}$ & $0.228 \pm 0.003 \%^{a}$ & $0.236 \pm 0.005 \%^{b}$ \\
\hline Geranial & $0.100 \%$ & $0.103 \pm 0.003 \%^{a}$ & $0.101 \pm 0.001 \%^{a}$ & $0.098 \pm 0.002 \%^{a}$ \\
\hline Valencene & $1.700 \%$ & $N Q$ & $N Q$ & $N Q$ \\
\hline TOTAL & $100.000 \%$ & $99.999 \pm 0.005 \%{ }^{a}$ & $99.510 \pm 0.005 \%$ b & $99.320 \pm 0.004 \%$ \\
\hline
\end{tabular}

$\mathrm{SD}=$ Standard Deviation; $\mathrm{NQ}=$ Not Quantified 
The concentrations of alpha-pinene, myrcene and geranial were close to those reported in literature, while the quantities of D-limonen (the main compound found in the OEO) were a little higher and the concentrations of octanal and linalol were slightly lower. In fact, the amounts of the substances contained in the OEO may vary according to harvesting time, soil, climate, extraction methods and other factors (SANTOS, SERAFINI and CASSEL, 2003).

The headspace methodology used to evaluate the encapsulation efficiency allowed the use of a small amount of sample $(1 \mathrm{~g})$ and avoided loss of volatiles. This could be achieved due to the fact that this analysis was coupled to gas chromatography, rendering possible to quantify the essential oil contained in the microparticles. The quantification of the essential oil encapsulated in the microparticles was performed by calculating the percent ratio between the final OEO's mass and the OEO's mass contained in the initial formulation, as shown in Table 5. The yielding of both encapsulation methods were high. In addition, Table 5 shows that the microparticles obtained by spray drying had encapsulation efficiency $(99.32 \%)$ statistically lower than those produced by coacervation $(99.51 \%)$, which may be related to the higher thermal stability of the coacervated microparticles, as shown in the TGA (Table 4) and DSC (Figure 10) curves.

The results of the current paper demonstrated that although both encapsulation methods presented high process yield, there are differences between them. Spray drying requires low operating costs and produces small-sized microcapsules with good stability. The microcapsules produced by spray drying and by coacervation have different release times of the essential oil. This was not the object of this study, but this might be important when deciding the best method to use depending on the application of the encapsulated oil. Coacervation is a satisfactory technique for thermal-sensitive materials such as essential oils for it does not use heat. The equipments used in coacervation are cheaper than in spray drying, however the operation costs are higher for the product obtained must be dried under controlled temperature and relative humidity. Because microparticles obtained by coacervation have higher thermal stability than those obtained by spray drying, coacervated microparticles may be used in foods that undergo intense thermal treatment. Consequently, the microencapsulation method may be selected according to the use of the final product, availability of equipment and relation between production cost and sales price of the microencapsulated essential oil.

\section{CONCLUSIONS}

In this work, polymeric microparticles containing orange essential oil were successfully obtained either by spray drying or by coacervation. The microparticles made from maltodextrin and modified starch and prepared by spray drying did not present cracks, suggesting the formation of a continuous film on the microparticles' external wall. The encapsulation efficiency for this system was $99.32 \%$. The microparticles made from sodium alginate and processed by coacervation followed of oven drying presented a flat homogeneous surface, rendering an efficiency of $99.51 \%$.

D-limonene was the main compound found in the essential oil, with an average concentration of $95.7 \%$, followed by mircene, representing $1.7 \%$. When encapsulated (by any of the two methods), the oil showed to be more stable to oxidation due to the presence of the polymeric microcapsule.

The higher thermal stability of the microparticles obtained by coacervation respect to spray drying is attributed to the effect of crosslinking of the sodium alginate polymer system, which leads to the formation of a polymeric network. The crosslinked sodium 
alginate has higher thermal stability (i.e. degrades in a longer time) than either modified starch or maltodextrin and holds the oil inside the capsule, increasing the boiling point of the encapsulated material. This behavior suggests a successful interaction between polymer and oil.

The microparticles formed by coacervation have higher thermal stability than those obtained by spray drying and the particle size distribution is more uniform. However, the spray dried particles also showed good uniformity. Anyhow, the encapsulation method (spray drying or coacervation) may be chosen basing on the final use of the product, production rate and system cost.

\section{RESUMO}

\section{EFICIÊNCIA DE ENCAPSULAÇÃO E ESTABILIDADE TÉRMICA DE ÓLEO ESSENCIAL DE LARANJA MICROENCAPSULADO POR SPRAY DRYING E POR COACERVAÇÃO}

Oóleo essencial de laranja foi microencapsulado por spray drying utilizandomaltodextrina e amido modificado com octenilsuccinato como agente carreador ou por coacervação seguida de secagem em estufa utilizando alginato de sódio como carreador. A influência dos diferentes métodos de microencapsulação e dos agentes carreadores nas características microscópicas e térmicas do produto e na eficiência de encapsulação foi investigada. De acordo com uma técnica baseada em extração headspace acoplada a cromatografia em fase gasosa, as eficiências de encapsulação foram superiores a $99 \%$ para ambos os métodos e o óleo foi composto essencialmente por D-limoneno (95,7\%). A coacervação e o spray drying produziram micropartículas de 1,02 $\mu \mathrm{m}$ e 908,63 $\mu \mathrm{m}$, respectivamente, o que aumentou a estabilidade térmica do óleo. No entanto, os coacervados mostraram estabilidade e ponto de ebulição térmica mais elevado do que as micropartículas secas por spray drying.

PALAVRAS-CHAVE: COACERVAÇÃO; SPRAY DRYING; ÓLEO ESSENCIAL DE LARANJA; MICROENCAPSULAÇÃO; ESTABILIDADE TÉRMICA.

\section{REFERENCES}

1 AGARWALL, P.; DOLLIMORE, D. The effect of chemical modification on starch studied using thermal analysis. Thermochimica Acta, v.324, n.1-8, 1998.

2 ARARUNA, S.M.; SILVA, A.H.; CANUTO, K.M.; SILVEIRA, E.R.; LEAL, L.K.A.M. Influence of process conditions on the physicochemical characteristics of cumaru (Amburana cearensis) powder produced by spray drying. Brazilian Journal of Pharmacognosy, v.23, n.1, p. 132-137, 2013.

3 BENELLI, P.; RIEHL, C.A.S.; SMÂNIA JR., A.; SMÂNIA, E.F.A.; FERREIRA, S.R.S. Bioactive extracts of orange (Citrus sinensis L. Osbeck) pomace obtained by SFE and low pressure techniques: Mathematical modeling and extract composition. The Journal of Supercritical Fluids, v.55, n.1, p. 132-141, 2010.

4 BERTOLINI, A.C.; SIANI, A.C.; GROSSO, C.R.F. Stability of monoterpenes encapsulated in gum arabic by spraydrying. Journal of Agricultural and Food Chemistry, v.49, p. 780-785, 2001.

5 BIZZO, H. R.; HOVELL, A.M.C.; REZENDE, C.M. Essential oils in Brazil: general aspects, development and perspectives. Química Nova, v.32, n.3, p. 588-594, 2009. (In Portuguese).

6 BOTREL, D.A.; BORGES, S.V.; FERNANDES, R.V.B.; CARMO, E.L. Optimization of fish oil spray drying using a protein: inulin system. Drying Technology, v.32, n.3, p. 279-290, 2014. 
7 BOTREL, D.A.; BORGES, S.V.; FERNANDES, R.V.B.; VIANA, A.D.; COSTA, J.M.G.; MARQUES, G.R. Evaluation of spray drying conditions on properties of microencapsulated oregano essential oil. International Journal of Food Science and Technology, v.47, n.11, p. 2289-2296, 2012.

8 BOTREL, D.A.; FERNANDES, R.V.B.; BORGES, S.V.; YOSHIDA, M.I. Influence of wall matrix systems on the properties of spray-dried Journal of Chemical Engineering and Chemistry, v.1, n.2, 2015.

9 CALISKAN, G.; DIRIM, S.N. The effects of the different drying conditions and the amounts of maltodextrin addition during spray drying of sumac extract. Food and Bioproducts Processing, v.91, n.4, p. 539-548, 2013.

10 CHANG, Y.X.; YANG, J.J.; PAN, R.L.; CHANG, Q.; LIAO, Y.H. Antihygroscopic effect of leucine on spray-dried herbal extract powders. Powder Technology, v.266, p. 388-395, 2014.

11 COSTA, J.M.G.; SILVA, E.K.; HIJO, A.A.C.T.; AZEVEDO, V.M.; MALTA, M.R.; ALVES, J.G.L.F.; BORGES, S.V. Microencapsulation of Swiss cheese bioaroma by spray-drying: Process optimization and characterization of particles. Powder Technology, v.274, p. 296-304, 2015.

12 COUTO, R.O.; CONCEIÇÃO, E.C.; CHAUL, L.T; OLIVEIRA, E.M.S.; MARTINS, F.S.; BARA, M.T.F.; REZENDE, K.R.; ALVES, S.F.; PAULA, J.R. Spray dried Rosemary extracts: physicochemical and antioxidant properties. Food Chemistry, v.131, n.1, p. 99-105, 2012.

13 DONG, Q.-Y.; CHEN, M.-Y.; XIN, Y.; QIN, X.-Y.; CHENG, Z.; SHI, L.-E.; TANG, Z.-X. Alginate-based and proteinbased materials for probiotics encapsulation: a review. International Journal of Food Science and Technology, v.48, n.7, p. 1339-1351, 2013.

14 DONG, W.; BODMEIER, R. Encapsulation of lipophilic drugs within enteric microparticles by a novel coacervation method. International Journal of Pharmaceutics, v.326, n.1-2, p. 128-138, 2006.

15 ESTEVINHO, B.N.; ROCHA, F.; SANTOS, L.; ALVES, A. Microencapsulation with chitosan by spray drying for industry applications - a review. Trends in Food Science and Technology, v.31, n.2, p. 138-155, 2013.

16 FERNANDES, R.V.B.; BORGES, S.V.; BOTREL, D.A. Gum arabic/starch/maltodextrin/inulin as wall materials on the microencapsulation of rosemary essential oil. Carbohydrate Polymers, v.101, p. 524-532, 2014.

17 GARGANO, A.C.; COSTA, C.A.R.A.; COSTA, M. Essential oils from Citrus latifolia and Citrus reticulata reduce anxiety and prolong ether sleeping time in mice. Tree and Forestry Science and Biotechnology, v.2, p. 121-124, 2008.

18 GONSALVES, J.K.M.C.; COSTA, A.M.B.; DE SOUSA, D.P.; CAVALCANTI, S.C.H.; NUNES, R.S. Microencapsulation of essential oil of Citrus sinensis (L) Osbeck by simple coacervation method. Scientia Plena, v.5, n.11, p. 1-8, 2009. (In Portuguese).

19 HIJO, A.A.C.T., COSTA, J.M.G., SILVA, E.K., AZEVEDO, V.M., YOSHIDA, M.I., BORGES, S.V. Physical and termal properties of oregano (Origanum vulgare L.) essential oil microparticles. Journal of Food Process Engineering, v.38, n.1, p. 1-10, 2015.

20 IONASHIRO, M.; GIOLITO I. Fundamentals of Thermogravimetry, Differential Thermal Analysis and Differential Scanning Calorimetry; Giz Editorial e Livraria Ltda: São Paulo, 2005. (In Portuguese).

21 JOYE, I.J.; McCLEMENTS, D.J. Biopolymer-based nanoparticles and microparticles: Fabrication, characterization, and application. Current Opinion in Colloid and Interface Science, v.19, n.5, p. 417- 427, 2014.

22 LEIMANN, F.V.; GONÇALVES, O.H.; MACHADO, R.A.F.; BOLZAN, A. Antimicrobial activity of microencapsulated lemongrass essential oil and the effect of experimental parameters on microcapsules size and morphology. Materials Science \& Engineering Biomimetic Materials, Sensors and Systems, v.29, p. 430-436, 2009.

23 LERTSUTTHIWONG, P.; NOOMUN, K.; JONGAROONNGAMSABG, N.; ROJSITTHISAK, P. Preparation of alginate nanocapsules containing turmeric oil. Carbohydrate Polymer, v.74, p. 209-214, 2008.

24 MARQUES, G.R.; BORGES, S.V.; MENDONÇA, K.S.; FERNANDES, R.V.B.; MENEZES, E.G.T. Application of maltodextrin in green corn extract powder production. Powder Technology, v.263, p. 89-95, 2014.

25 MARRETO, R.N.; ALMEIDA, E. E.C.V.; ALVES, P. B.; NICULAU, E.S.; NUNES, R.S.; MATOS, C.R.S.; ARAUJO, A.A.S. Thermal analysis and gas chromatography coupled mass spectrometry analyses of hydroxypropylcyclodextrin inclusion complex containing Lippia gracilis essential oil. Thermochimica Acta (Print), v.47, 2008. 
26 MATALANIS, A.; DECKER, E. A.; MCCLEMENTS, D. J. Inhibition of lipid oxidation by encapsulation of emulsion droplets within hydrogel microspheres. Food Chemistry, v.132, n.2, p. 766-772, 2012.

27 MISHRA, P.; MISHRA, S.; MAHANTA, C.L. Effect of maltodextrin concentration and inlet temperature during spray drying on physicochemical and antioxidant properties of amla (Emblica officinalis) juice powder. Food and Bioproducts Processing, v.92, n.3, p. 252-258, 2014.

28 MOSQUEIRA, V.C.F.; LEGRAND, P.; PINTO-ALPHANDARY, H.; PUISIEUX, F.; BARRATT, G. Poly (D,L-lactide) nanocapsules prepared by solvent displacement process: influence of composition on physico-chemical and structural properties. Journal Pharmacological Science, v.89, p. 614-626, 2000.

29 PAULA, H.C.B.; OLIVEIRA, E.F.; ABREU, F.O.M.S.; de PAULA, R.C.M. Alginate/cashew gum floating bead as a matrix for larvicide release. Materials Science and Engineering. C, Materials for Biological Applications, v.32, n.6, p. 1421-1427, 2012.

30 POURASHOURI, P.; SHABANPOUR, B.; RAZAVI, S.H.; JAFARI, S.M.; SHABANI, A.; AUBOURG, S.P. Impact of wall materials on physicochemical properties of microencapsulated fish oil by spray drying. Food and Bioprocess Technology, v.7, p. 2354-2365, 2014.

31 QV. X. Y.; ZENG, Z. P.; JIANG, J. G. Preparation of lutein microencapsulation by complex coacervation method and its physicochemical properties and stability. Food Hydrocolloids, v.25, p. 1596-1603, 2011.

32 RAMAKRISHNAN, S.; FERRANDO, M.; ACEÑA-MUÑOZ, L.; MESTRES, M.; DE LAMO-CASTELLVÍ, S.; GÜELL, C. Influence of emulsification technique and wall composition on physicochemical properties and oxidative stability of fish oil microcapsules produced by spray drying. Food and Bioprocess Technology, v.7, n.7, p. 433-446, 2014.

33 RÉ, M.I. Formulating drug delivery systems by spray-drying. Drying Technology, v.24, n.4, p. 433-446, 2006.

34 SANTOS, A.C.A., SERAFINI, L.A., CASSEL, E. Estudo de processos de extração de óleos essenciais e bioflavonóides de frutas cítricas. Caxias do Sul: EDUCS, 2003, p. 19-29.

35 SARAVANAN, M.; RAO, K.P. Pectin-gelatin and alginate-gelatin complex coacervation for controlled drug delivery: Influence of anionic polysaccharides and drugs being encapsulated on physicochemical properties of microcapsules, Carbohydrate Polymers, v.80, p. 808-816, 2010.

36 SCHAFFAZICK, S.R.; POHLMANN, A.R.; MEZZALIRA, G.; GUITERRES, S.S. Development of nanocapsule suspensions and nanocapsule spray-dried powders containing melatonin. Journal Brazilian Chemistry Society, v.17, p. 562-569, 2006.

37 SILVA, P.I.; STRINGHETA, P.C.; TEÓFILO, R.F.; OLIVEIRA, I.R.N. Parameter optimization for spray-drying microencapsulation of jaboticaba (Myrciaria jaboticaba) peel extracts using simultaneous analysis of responses. Journal of Food Engineering, v.117, n.4, p. 538-544, 2013.

38 SINGH, S.; DIXIT, D. A review on spray drying: emerging technology in food industry. International Journal of Applied Engineering and Technology, v.4, n.1, p. 1-8, 2014.

39 SOLIMAN, E.A.; EL-MOGHAZY, A.Y.; MOHY EL-DIN, M.S.; MASSOUD, M.A. Microencapsulation of Essential Oils within Alginate: Formulation and in Vitro Evaluation of Antifungal Activity, Journal of Encapsulation and Adsorption Sciences, v.3, p. 48-55, 2013.

40 TAN, L.H.; CHAN, L.W.; HENG, P.W.S. Alginate/starch composites as wall material to achieve microencapsulation with high oil loading. Journal of Microencapsulation, v.26, n.3, p. 263-271, 2009.

41 TEODORO, R.A.R.; FERNANDES, R.V.B.; BOTREL, D.A.; BORGES, S.V.; SOUZA, A.U. Characterization of microencapsulated rosemary essential oil and its antimicrobial effect on fresh dough. Food and Bioprocess Technology, v.7, n.9, p. 2560-2569, 2014.

42 TOVAR, L.P.; MACIEL, M.R.W.; PINTO, G.M.F.; MACIEL FILHO, R.; GOMES, D.R. Factorial design applied to concentrate bioactive component of Cymbopogon citratus essential oil using short path distillation. Chemical Engineering Research \& Design, v.88, n.2, p .239-244, 2010.

43 VELÁZQUEZ-CONTRERAS, C.; OSORIO-REVILLA, G.; GALLARDO-VELÁZQUEZ, T. Encapsulation of orange essential oil in a spout-fluid bed dryer with a draft tube on a bed of inert solids. Drying Technology, v.32, n.14, p. 1718-1726, 2014.

44 WANG, S.; GUO, S.; CHENG, L. Disodium norcantharidate loaded poly( $\varepsilon$-caprolactone) microspheres I. Preparation and evaluation. International Journal Pharmaceutics, v.350, p. 130-137, 2008. 
45 YU, L.; CHRISTIE, G. Measurement of thermal transitions using differential scanning calorimetry. Carbohydrate Polymers, v.46, n.2, p. 179-184, 2001.

\section{ACKNOWLEDGEMENTS}

The authors would like to thank CAPES Brazil (Coordination for the Improvement of Higher Education Personnel) for the financial support. 